\title{
Linking Participation and Built Environment Education in Urban Planning Processes
}

\author{
Angela Million*, Anna Juliane Heinrich \\ Chair of Urban Design \& Urban Development, Department of Urban \& Regional Planning (ISR), Faculty VI \\ Planning - Building - Environment, Berlin Institute of Technology, Berlin, Germany \\ Email: a.million@isr.tu-berlin.de
}

Received 26 September 2014; revised 2 November 2014; accepted 7 November 2014

Copyright (C) 2014 by authors and Scientific Research Publishing Inc.

This work is licensed under the Creative Commons Attribution International License (CC BY).

http://creativecommons.org/licenses/by/4.0/

cc) (i) Open Access

\begin{abstract}
The article reflects in theory and practice on links between built environment education (BEE) and youth participation in urban planning processes. Taking into account tempirical knowledge on linkages between participation and educational processes, the findings show that BEE is an important way to qualify current practices of participation. The theoretical discussion is reflected on the EU-project "Fantasy Design-Children in Community" and the national German youth workshop "Young Cities Now! Youth. City. Laboratory". The authors conclude that a debate on the inclusion of BEE in participation processes is necessary to support young people to participate in urban planning processes. But further investigation is needed to provide empirical evidence on impacts and outcomes and to discuss contradictions.
\end{abstract}

\section{Keywords}

Built Environment Education, Design Education, Participatory Design, Youth Participation, Urban Planning

\section{Introduction}

Children and adolescents have a vital understanding of spaces, buildings and neighbourhoods. They are experts in their own needs. They will be "framers" and decision makers in cities of tomorrow. Hence, the participation of children and young people in planning processes receives more and more attention in urban planning. Planning cities for children and young people today still means planning for a largely unheard section of society. There is a rising acceptance and willingness to let young people and children participate and collaborate with adults to discuss, plan and implement improvements in their cities and neighbourhoods. At the same time par-

Corresponding author. 
ticipation processes place enormous demands on young people. Research so far lacks investigations and discussions on the high demands on youths in design and city planning participation processes and questions about what kind of education is required.

Built environment education is a multifaceted and interdisciplinary way for young people to learn about their own environment and gain necessary skills in designing it. Educational processes that focus on design and planning skills can help children and young people to form a stronger and more reflective voice when asked to formulate their spatial needs.

Both authors of this paper are active in built environment education and participation of children and young people in urban planning processes. After several years of practice in both fields we as authors see that the overlapping of built environment education and community participation can benefit both. We experienced in practice many situations in which practice of built environment education and participation enhanced each other. With this paper we want to initiate a debate on linkages between the two fields of action in order to foster future practice of educators and participation practitioners and to encourage scientific discussions in the fields of urban planning, education and participation. In order to do so, this article introduces both concepts and afterwards discusses practical experience from two projects which worked at the interface between community participation and built environment education. The examples will be reflected in the light of the existing theoretical debate.

\section{Youth Participation in Planning Processes}

Communities today face manifold challenges of an organisational, economic and social nature. The creation of youth- and child-friendly cities and neighbourhoods (European Network Cities for Children:

www.citiesforchildren.eu) involves a complex and difficult process of negotiation (Christensen \& O'Brian, 2003: p. 1). An important basis for this is a broad and inclusive decision-making pattern, which engages stakeholders with different backgrounds, motivations, opinions and resources and also makes the voices of young people heard (Niemann, Schauz, Andreas, Uttke, Heinrich, \& Edelhoff, 2013: pp. 9-11). One important way to broaden participation and to move to a more generationally inclusive city is through the involvement of youth (Bertelsmann Stiftung, 2007: pp. 7, 78-80; Meinhold-Henschel, 2007b: p. 221; Mullahey, Susskind, \& Checkoway, 1999: p. 5):

"From the perspective of community planning, influential youth participation occurs when:

- actions aim to intervene in existing conditions

- involvement is part of the public dialog and decision making

- engagement is influential and changes are significant” (Mullahey, Susskind, \& Checkoway, 1999: pp. 3-4).

Characteristic of community participation is that young people act as stakeholders in the political arena and not in a pedagogical environment (Knauer \& Sturzenhecker, 2005: pp. 19-20). In current participation processes young people identify problems, they analyse causes and resources in order to solve these problems, mobilise other stakeholders, they formulate goals and design action plans, they implement actions and evaluate their outcomes (Mullahey, Susskind, \& Checkoway, 1999: p. 5).

A typology of different kinds and levels of participation is provided by Hart's ladder of young people's participation (first published in 1992), which is based on Arnstein's seminal ladder of participation (1969). The ladder distinguishes non-participation and diverse degrees of participation. The named degrees of participation embrace

- assigned but informed,

- consulted and informed,

- adult-initiated, shared decisions with children,

- child-initiated and directed, and

- child-initiated, shared decisions with adults.

These different degrees describe grades of "agency or participatory engagement by young people" (Hart, 2008: p. 23). In 2008 Hart wrote a paper reflecting on the ladder of youth participation and its manifold interpretations since its publication. He concludes that the ladder metaphor is unfortunate because it suggests the assumption that the higher rugs of the ladder are necessarily superior to the ones beneath. Hart stresses that this is not the case but that the degree of participation simply needs to suit the respective project.

Within the five degrees of participation different forms of participation can be distinguished. While there is a high diversity of methods Stange (2008) gives an overview summarising different categories of participation methods: 
1) advocacy representation of youth's interests,

2) youth participation in institutions of the adult world,

3) selective participation,

4) everyday participation,

5) representative participation (e.g. children and youth parliaments),

6) open forms and forums, and

7) project approaches to participation.

Within this categorisation the first aspect describes "policies for young people", the second to fourth point define "policies with young people" and the last three categories outline "policies by young people" (Moser, 2010: p. 212). An investigation of the youth participation practice in German cities revealed that all three policies are of importance today as youth engagement is sought for in different planning tasks and scales (Niemann, Schauz, Andreas, Uttke, Heinrich, \& Edelhoff, 2013: p. 8).

The justifications for youth participation are diverse and refer e.g. to civil law, democratic and political theory, educational, ethical and moral theory and service orientation (Betz, Gaiser, \& Pluto, 2011: p. 3). The most important legal point of reference is The United Nations Convention on the Rights of the Child (1989). This international convention discusses children's and adolescent's right to participation as one of its main topics and has thus contributed to an appreciation and critical reflection on youth participation in many countries (Lundy, 2007; Meinhold-Henschel, 2007a: p. 9). Furthermore, the United Nations action plan for sustainable development, namely Agenda 21, and its Local Agenda 21 processes strengthen the role of major groups in development processes including the role of young people (Hart, 1997: p. 23). In Germany, an important motivation which drives youth participation in communities is the common goal to be family-friendly and thus to attract families and enterprises (Meinhold-Henschel, 2007a: p. 12).

Despite these legal foundations of and motivations for youth participation, adolescents are generally not integrated in traditional planning processes of urban development in Germany (Bundesministerium für Verkehr, Bau und Stadtentwicklung [BMVBS], 2010: p. 10). Participation is often part of one-off projects rather than integrated political process. So far, youth participation is neither a cross-cutting issue in city planning nor is it part of planning culture (Moser, 2010: p. 19). Additionally, the quality of participation processes is often poor: none sustainable, unprofessionally implemented, reaching only a small group of participants (Meinhold-Henschel, 2007a: pp. 12-13).

\section{Built Environment Education (BEE)}

Educational activities related to the built environment incorporate a broad field of activity focuses and approaches to education such as environmental education, architectural education, design education, and (visual) arts education. "The common ground of all these various types of learning activities for children and young people is the use of buildings, places and spaces as a context for learning” (Uttke, 2012: p. 4).

Built environment education (BEE) is conceptualised as a cross-cutting subject which utilises the built environment as a learning resource taking into consideration cities, towns, villages, buildings, landmarks and public spaces. Common BEE activities are, for example, visits to certain places, school-projects supervised by design professionals such as architects or urban planners and participatory school design processes. Furthermore, BEE canthematise the relation between people and the built environment or the design of spaces in order to trigger learning processes (Engaging Places network, 2012a).

Built environment education is multifaceted and interdisciplinary. It incorporates aspects of architecture, urban design, city and regional planning and landscape design. Consequently, educators from these different fields cooperate in projects and programmes of BEE. Furthermore, schools and teachers, parents, education authorities and governments can be partners (Engaging Places network, 2012a; Uttke, 2012).

The different approaches to BEE are all forms of cultural education and share common aims (Krings \& Hasreiter, 1995; Uttke, 2012: p. 4). Objectives and learning targets of BEE are amongst others (Engaging Places network, 2012b; International Union of Architects [UIA], 2008: p. 5):

- to develop awareness and understanding of the local environment and appreciation for architecture and design,

- to learn about stakeholders, rights and responsibilities in the design of the environment and possible careers in the built environment, 
- to support the development of responsibility in view of contributions to society and sustainable development,

- to broaden personal, learning and thinking skills such as creativity, confidence, self-management, team-work, critical reflection and judgement, participatory and communicative skills, and

- to experience analytical and conceptual working methods.

The development of concepts and ideas for BEE has increased in the past 20 years and receives growing attention nowadays. International networks, have been installed to discuss, promote and support BEE. Examples for this are amongst others PLAYCE (http://www.playce.org/) and the International Union of Architects (UIA) Built Environment Education Network (http://uia-architecture-children.bak.de/index-en.html).

\section{Linking Built Environment Education and Youth Participation}

The linkages between built environment education and youth participation in planning processes seem to be particularly evident on first view. As Hart's ladder of youth participation introduces different degrees of participation, it seems obvious that the higher the rug and thus the higher the degree of agency by young people, the more demanding and challenging youth participation becomes for young people. Since participation places high demands on young participants on all rugs of the ladder, education can be regarded as a necessary component of participation processes (Adams, 2006: p. 9; Bertelsmann Stiftung, 2009: pp. 60-61; Knauer \& Sturzenhecker, 2005: p. 20).

BEE promotes abilities, which are relevant for decision-making and participation. In contrast to education for participatory processes it provides awareness and knowledge about the built environment and skills to voice and generate spatial ideas (see objectives and learning targets of BEE). At the same time the BEE frames itself as a possible starting point for further participation in the community (Räsänen, 2006: p. 14; Uttke, 2012). BEE can "inculcate [...] a desire to participate in the complex and magical process that constructs the house, the town and the region" (UIA, 2008: p. 4).

A central motive of community participation is the assumption that participation entails a great variety of educational and socialisation processes (Bundesjugendkuratorium [BJK], 2009: p. 31; Knauer \& Sturzenhecker, 2005: p. 3; Mullahey, Susskind, \& Checkoway, 1999: p. 3). Key qualifications such as self-reliance, communication skills and the development of own viewpoints can be strengthened (Knauer \& Sturzenhecker, 2005: p. 3; Winklhofer \& Zinser, 2008: p. 72). “Through first-hand experience [in participation processes], young people are building self-reliance, connecting with others, and learning about their inner resources and their own creative potential to forge a new sense of what is possible.” (Mullahey, Susskind, \& Checkoway, 1999: p. 1).

Despite these linkages theoretical concepts of BEE and participation rarely focus on mutual references and strategic links between one another. So far, there is a general agreement that participation automatically implies educational processes (Düx \& Sass, 2005: p. 397; Winklhofer \& Zinser, 2008: p. 72). Nonetheless, the assumption about this connection between participation and education lacks empirical evidence (Düx \& Sass, 2005: p. 397; Prein, Sass, \& Züchner, 2009: pp. 530-531).

A strong focus in research regarding these educational processes so far is on participation as an experience and training ground for democracy and civic education (Hafeneger, 2005: p. 27; Knauer \& Sturzenhecker, 2005: p. 11). In this sense, empirical studies prove a strong connection between education and participation in the way that an increasing level of education increases the general political interest, trust in social institutions and participation in organisations (Winklhofer \& Zinser, 2008: pp. 77-78): "Young people need the experience of genuine participation and knowledge of the responsibilities of real citizenship to become effective decision makers. [...] A community planning process can serve as a springboard to actualize democratic citizenship” (Mullahey, Susskind, \& Checkoway, 1999: p. 6).

Initial findings about the educational effects of participation in general are presented in the investigation by Düx and Sass (2005). They analyse informal learning among youth in volunteering settings. Their results are based on 72 face-to-face interviews with adolescents and young adults who were either at the time or previously engaged in voluntarily work. In addition, their findings draw on standardised telephone interviews with 1500 people who were engaged in voluntary activities as adolescents and 500 people who did not engage in community commitment in their youth. The interpretation of the empirical material suggests that young people's voluntary commitments lead to a development of skills, which meet the conflicting demands of modern society. Skills such as personal, social and technical skills, responsibility, democratic participation and moral values are promoted (Düx \& Sass, 2005: pp. 398, 408). On top of this, a recent review of international research on issues of 
acquisition of competencies and learning through commitment and participation can be found in Lerner, Alberts and Bobek (2007) (Prein, Sass, \& Züchner, 2009: p. 532).

Despite the presented recommendation to link built environment education and youth participation in planning processes the authors are aware of the risks and problems this might incorporate. "Young people's work that focuses on individual learning and development, rather than on changing their surroundings, is not real participation” (Mullahey, Susskind, \& Checkoway, 1999: p. 4). In this sense, Knauer and Sturzenhecker (2005) come to the conclusion that by definition youth participation is not pedagogical because here youths act as political actors and policy-maker. But because this seems hardly manageable without certain knowledge and skills, coaching and training should be integrated in participation processes (Knauer \& Sturzenhecker, 2005: pp. 1920).

Francis and Lorenzo (2002) define seven realms of children's participation in city design and planning to point out development stages since the 1970s. In the realm of "Children as Learner" they describe the approach of participation through environmental education and learning, where the "learning outcomes of participation is as important as physical change” (Francis \& Lorenzo, 2002: p. 161). It is criticised, that perceptions are changed and skills are acquired but changes in the built environment are rare. At the same time they also acknowledge, that education can be "a specialized but active part of child participation projects" (Francis \& Lorenzo, 2002: p. 161). Even in their favoured realm of a proactive "Participation with vision" they ask for participation "as a communicative, educational activity" (Herrington, 1999 cited in Francis \& Lorenzo, 2002: p. 164). All arguments show, that participation processes must not be instrumentalised as pure educational processes. But it seems necessary and productive to integrate educators and built environment education in youth participation.

Despite the debate on the educational effects of participation and participatory approaches to education there is little discussion on a purposeful integration of BEE and planning participation. In the following, study cases will be presented in order to shed light on the linkages between participation and education and to give first insights coming out of practice.

\subsection{Case Studies Linking Built Environment Education and Youth Participation}

As an approach to a deepened understanding of the linkages between participation and built environment education, the authors' practical experiences from projects at the interface of the two fields will be described and analysed in the following. First, findings from the EU-project "Fantasy Design in Community" will be summarised. The project was designed to promote built environment education and focused on participatory design with young people. The second example of practical experience presents an attempt to incorporate the viewpoint of adolescents on participation and built environment education. The findings are derived from the youth workshop "Young Cities Now!" which was conducted with young people who participated in diverse planning processes all over Germany in 2009. One result of the workshop was a manifesto drawn up by the participants.

The two projects "Fantasy Design in Community" and "Young Cities Now!" were chosen for the study at hand because both projects have been subject to research by the authors before (Uttke \& Heinrich, 2012; Heinrich, 2010). Hence, there was already a database that meets scientific standards and which could be used for an integrated interpretation focusing on the over lappings of built environment education and community participation.

\subsubsection{Fantasy Design—Children in Community}

In the EU-project “Fantasy Design—Children in Community” innovative methods of design education were explored between 2009 and 2011. The project manager describes Fantasy Design as "a design education initiative [...]. Its core idea is to give children and young people an opportunity to work with designers and to display their own design thinking in an international exhibition” (Kapanen \& Svinhufvud, 2011: p. 9). The project focused on participatory design processes involving young people in design projects, solving problems in their own environment and everyday life and discussing these issues in an international community. Million-Uttke and Heinrich conducted the evaluation of this EU-project in 2011 (Uttke \& Heinrich, 2012). The chapter is mainly based on this report.

"Fantasy Design—Children in Community" was realised by partners from four different countries: Design Museum Helsinki (Finland), University College Sealand (Denmark), Design museum Ghent (Belgium) and National Museum of Decorative Art Madrid (Spain). The Fantasy Design (FD) project consisted of activities at na- 
tional and international levels. Locally developed design projects focusing on different tasks and at different scales were conducted in all four countries, in each case working with designers and other professionals. In total Fantasy Design consisted of 18 projects in Finland, Denmark and Belgium and 12 workshops in Spain (Kapanen \& Svinhufvud, 2011: pp. 113-116) with a participation of about 400 students from elementary up to secondary schools, including youth centres. An international web site (www.fantasydesign.org) was used for the documentation of the projects, for compilation of information on design education in general (e.g. learning material for teachers) and communication within projects and amongst different projects. Throughout the process two international conferences were held. An international touring exhibition presenting design processes and products was both highlight and closing event of the project.

The project was based on earlier international design educational programs: the first, Fantasie Design "(engl. Fantasy Design) project (1998-2000) and the second" "Fantasy Design-Children and Young People as Designers” (2003-2006) project. Those first two Fantasy Design (FD) projects mainly focused on product design (Uttke \& Heinrich, 2012: p. 3). "Fantasy Design—Children in Community" (FD 3) built on key ideas and factors in success of the first two FD projects. Furthermore, deficits of the former projects were compensated for and new components were added to the concept. One of the most important innovations of FD 3 was the explicit focus on community aspects and the built environment, such as:

- "looking at design as a tool in building a sustainable and socially inclusive environment,

- working in collaboration with local authorities in planning and environment,

- including cross-sectoral aspects in local work, e. g. collaborating with social and health sectors, culture and administration,

- creating a European design community within the project” (Application Form to the EU Culture Programme \& Education and Culture DG application FD 3: p. 8).

The spectrum of realised projects under the umbrella theme "Fantasy Design in Community" was very broad. Projects included re-design of central spaces in communities, such as school yards, parks, youth houses and spaces for the youth, community centres and neighbourhood spaces. Other projects focused on a communicative and collaborative process in product design discussing the needs of participants and clients in a community. Within the local design processes designers and educators with different professional backgrounds as well as local actors were partners assisting the children with their designs.

Within the various projects different methods and principals were applied: young people worked as designers in teams, collaborations with local partners were built up and participatory design processes were created. Supporting learning with design and promoting design methods in education were main principles of this design education project, All projects were intended to trigger learning processes through personal experience and allow the exploration of creativity and innovation through "real" design projects (Application Form to the EU Culture Programme \& Education and Culture DG application FD 3: p. 8).

The aim of the evaluation was to reflect on outcomes of the project. The methodology of the evaluation included a workshop with the four national coordinators of the project, face-to-face and e-mail interviews with several participants such as educators and designers, desktop studies of the Fantasy Design web site and documents as well as self-evaluations by the national coordinators and finally a visit to the international Fantasy Design touring exhibition in Ghent (Figures 1-3).

Benchmarks for the evaluation were the project's objectives as described in the project application:

1) "to deepen and to extend the collaboration with central organizations in design education,

2) to promote contents and activities of innovative design education in Europe,

3) to create for children and young people a framework for informal learning and networking in local communities through real design tasks,

4) to use the possibilities of digital media (interactive web site) for collaboration and cross-cultural dialogue between children, young people, designers, educators and other stakeholders” (Uttke \& Heinrich, 2012: p. 11).

As a participatory design project Fantasy Design and its local projects operated at the interface of (built environment) education and youth participation. Particularly important for the examination of linkages between the two issues is the third goal, which addresses the framework for informal learning and networking in local communities. The evaluation stresses how closely related the aspects of BEE and participation are. Often education and participation are hardly separable within a project for both are fundamental for a successful process and high quality products. 


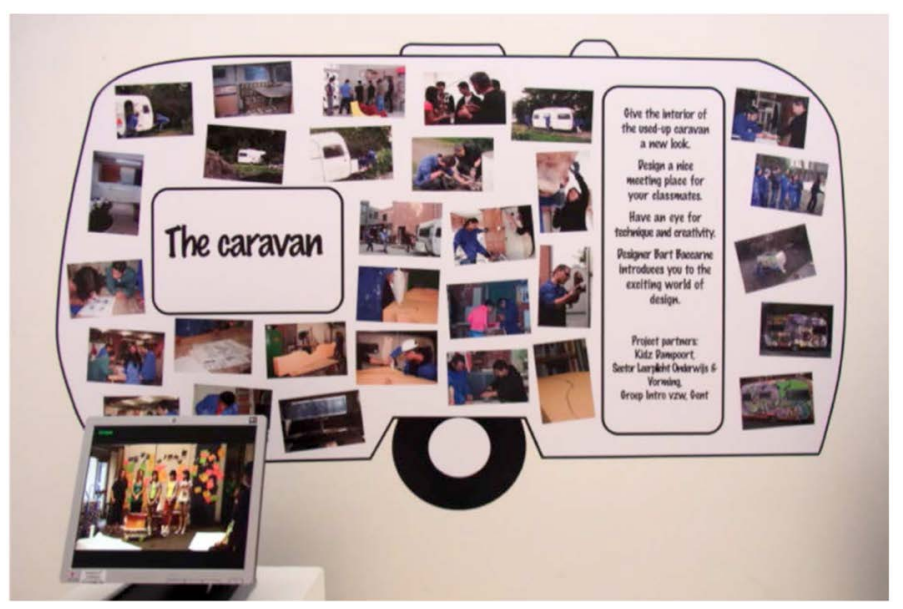

Figure 1. "Fantasy Design in Community" local youth project in Ghent (Photograph: A. Million).

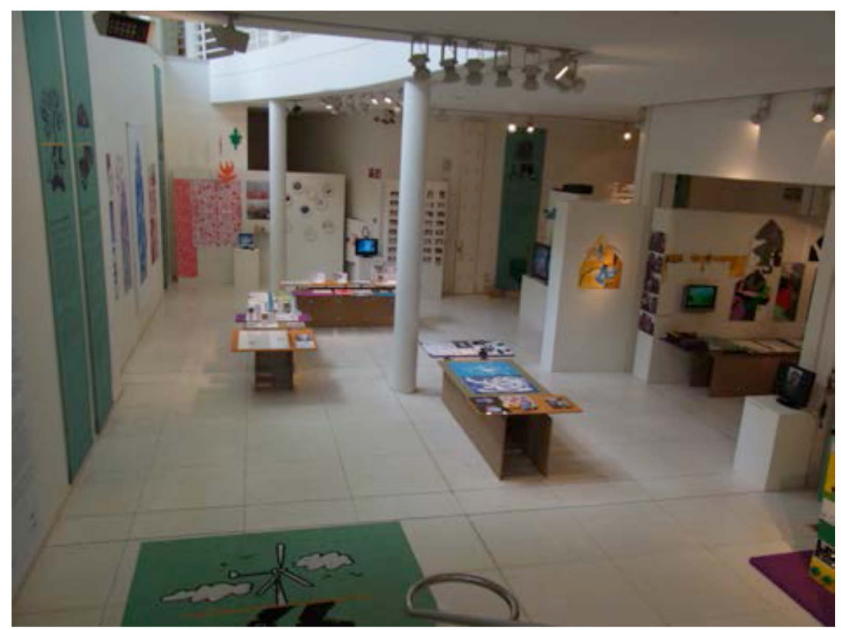

Figure 2. "Fantasy Design in Community" touring exhibition in Ghent (Photograph: A. Million).

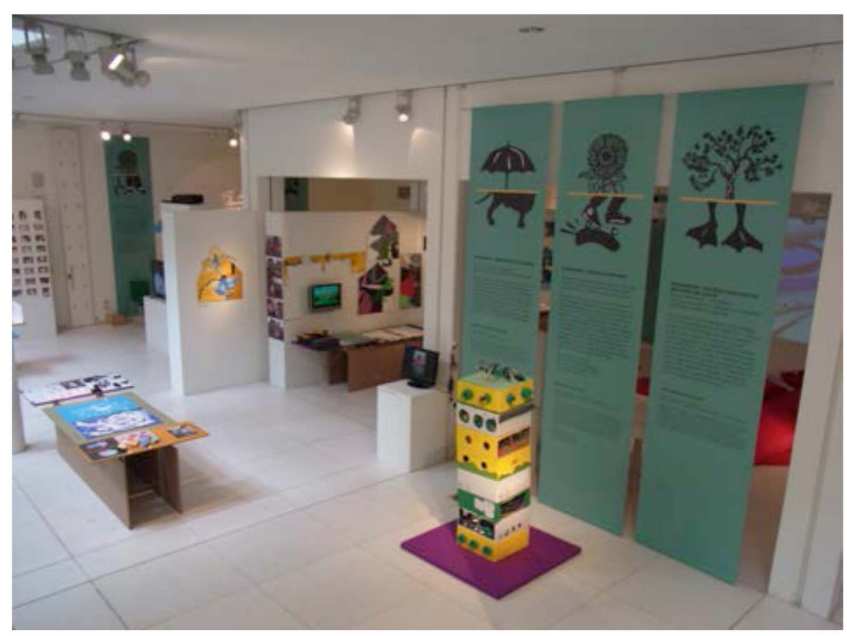

Figure 3. "Fantasy Design in Community" touring exhibition in Ghent (Photograph: A. Million). 
Each local project of FD 3 proceeded from a quasi-real and life design task such as the (re-)development or (re-)design of a certain place within the community or existing needs of local stakeholders. This relation to young people's own environment and daily problems and needs gave the projects high authenticity. FD was originally conceptualised as an educational project. The task to engage in community design was used to give the young people the opportunity to directly participate in urban design processes involving local politicians, architects and urban planners. Instead of “just” learning something about design in community in theory or exercising design projects completely detached from the current local development, the young participants were able to actually see their own ideas become reality in objects or changes of their local environment. This practical and participatory component gave the young people a high motivation to learn about design because they were eager to realize their own high quality projects. Project authors-social and community worker and art teacher (in the project teaming up with designer, architects and artists)—confirmed, that students were engaging a lot more in the projects compared to other. The young participants appreciated project components such as visits to local design museums and sessions on designerly ways of thinking. Such obviously educational components seemed to be highly accepted by the participants as helpful for their own design processes.

Compared to earlier Fantasy Design programs, the program authors_-all coming from the field of museum pedagogy_concluded, that being empowered to actually change their own environment, seemed to give the young people a strong feeling of appreciation and acknowledgement. They experienced how they can influence their surrounding and implement own ideas. The approach of learning-by-doing triggered their creativity and allowed them learning about design by playful, but life means. This could be important for future participation and commitment in community development because the participants were very positive and motivated at the end of the project and inhibitions for participation processes were overcome through the projects. Statements from youth workers from Finland support this assumption. They report that since the involvement in Fantasy Design young people as well as youth workers are for example no longer "interested in just buying new furniture for the yard when they can make it in a more special way by building and recycling” (Kapanen cited in Uttke \& Heinrich, 2012: p. 44).

\subsubsection{Young Cities Now!}

An important aspect of the discussion on youth participation is the viewpoint of young people themselves, as perspective is a factor in the realisation of successful youth participation (Bertelsmann Stiftung, 2009: p. 19). Therefore, young people's ideas and criticisms in view of community participation will also be considered in the following case study. It will be seen, that young people strongly link the issues of participation and education.

The workshop "Young Cities Now! Jugend. Stadt. Labor” (Young Cities Now! Youth. City. Laboratory, www.youngcitiesnow.de) was conducted in Berlin, Germany by the non-profit organisation JAS Jugend Architektur Stadt e. V. (Youth Architecture City) in November 2009. One of the authors was herself conceptualising and conducting the workshop. The other author accomplished a scientific analysis of all material, which was produced during the workshop by the participants. Inside knowledge and the scientific report (Heinrich, 2010) are the bases of the chapter.

"Young Cities Now!" was a project within the research field “Adolescents in Urban Neighbourhoods” of the German Federal Institute for Research on Building, Urban Affairs and Spatial Development. This is one of the research fields within the research programme "Experimental Housing and Urban Development" of the German Federal Ministry of Transport, Building and Urban Development. The aim of the research field is to develop methods and strategies for youth participation on different levels of urban and neighbourhood development. In the long term the projects within this research field are intended to support the establishment of a youth participation culture and thus contribute to the creation of youth-friendly cities (Bundesinstitut für Bau-, Stadt- und Raumforschung [BBSR], 2009b: pp. 21-22; BBSR, 2010a).

In May 2009 a call for projects for the research field “Adolescents in Urban Neighbourhoods” was launched. 31 projects all over Germany were chosen from 220 applications. The range of applied methods and conducted projects was very broad - the adolescents used new media, made films and composed songs, they created art initiatives and festivals. Additionally, “Young Cities Now!” was selected as an add-on project inviting two representatives of each of the 31 pilot projects to a common workshop. The aim of this workshop was to give the youth ambassadors the opportunity to reflect, discuss and communicate their different experiences. As a result a manifesto was written in order to set an impulse to foster youth participation in planning processes (BBSR, 2012; BBSR, 2010b; BBSR, 2009a: p. 29). In total 42 adolescents age 12 to 22 joined the three-day workshop in Ber- 
lin. The major topics they discussed were:

- participation,

- communal life and neighbourhood,

- sport and action,

- chill out,

- art,

- music, and

- mobility (BBSR, 2010b).

First a world café allowed all youngsters to share experiences, ideas and criticism on all of the seven main issues. In the further course of the workshop small groups focused on a single topic each (Figure 4). After deepened discussions they formulated paragraphs and catchy slogans for the manifesto and created illustrations to underline their statements (Figure 5). Finally, they presented their "Young Cities Now!" manifesto to representatives from the Ministry of Transport, Building and Urban Development (Figure 6) (BBSR, 2010b; Heinrich, 2010: pp. 16-18; Jugend Architektur Stadt e. V. [JAS], 2009).

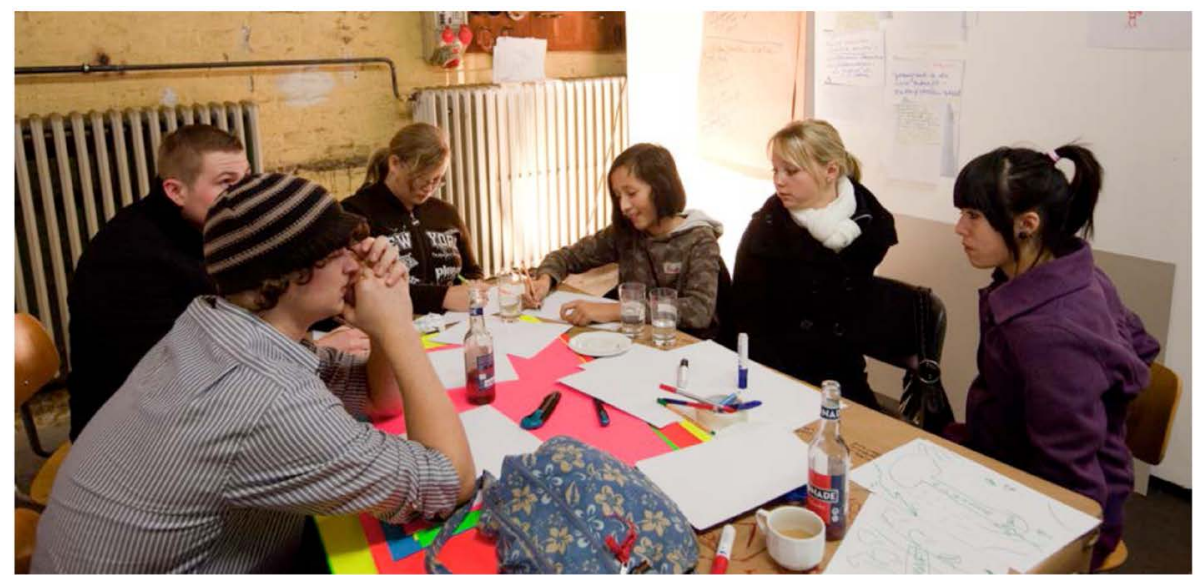

Figure 4. Group discussion at the "Young Cities Now!" workshop (Photograph: A. Meichsner, JAS e. V.).

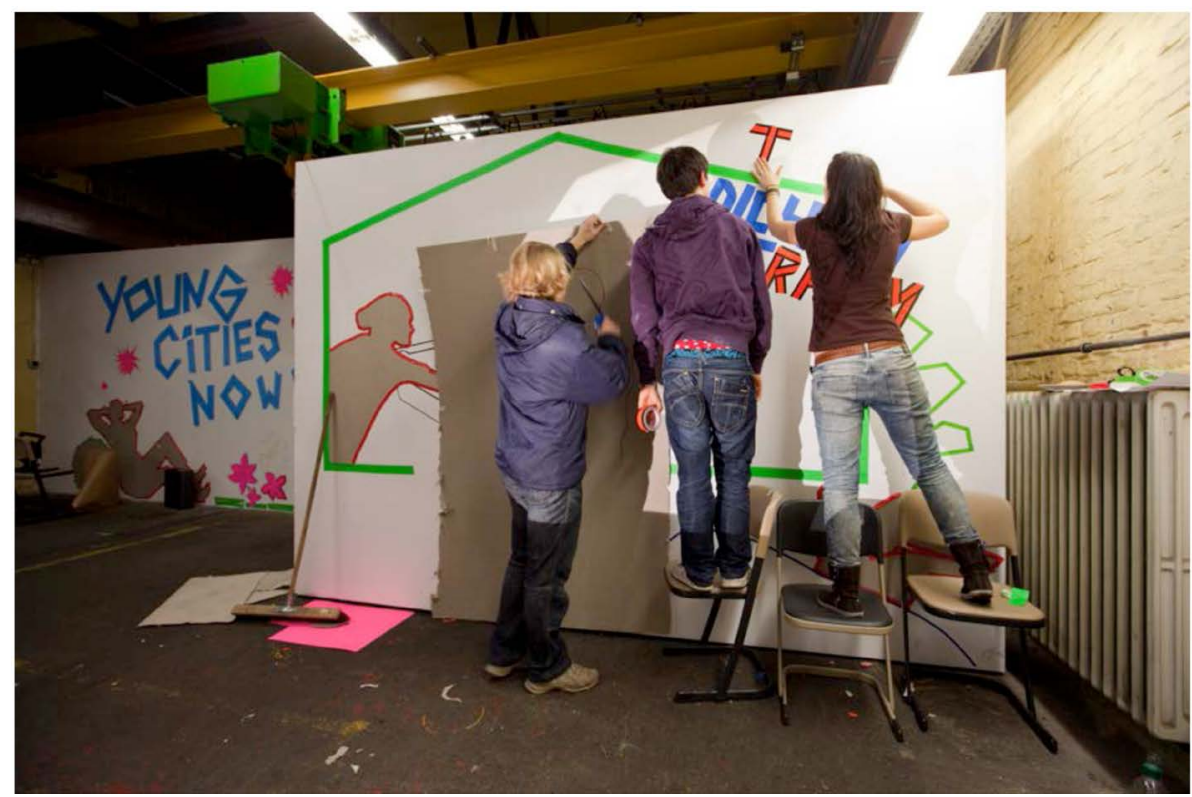

Figure 5. Visualizing their demands for the "Young Cities Now!” manifesto (Photograph: A. Meichsner, JAS e. V.). 


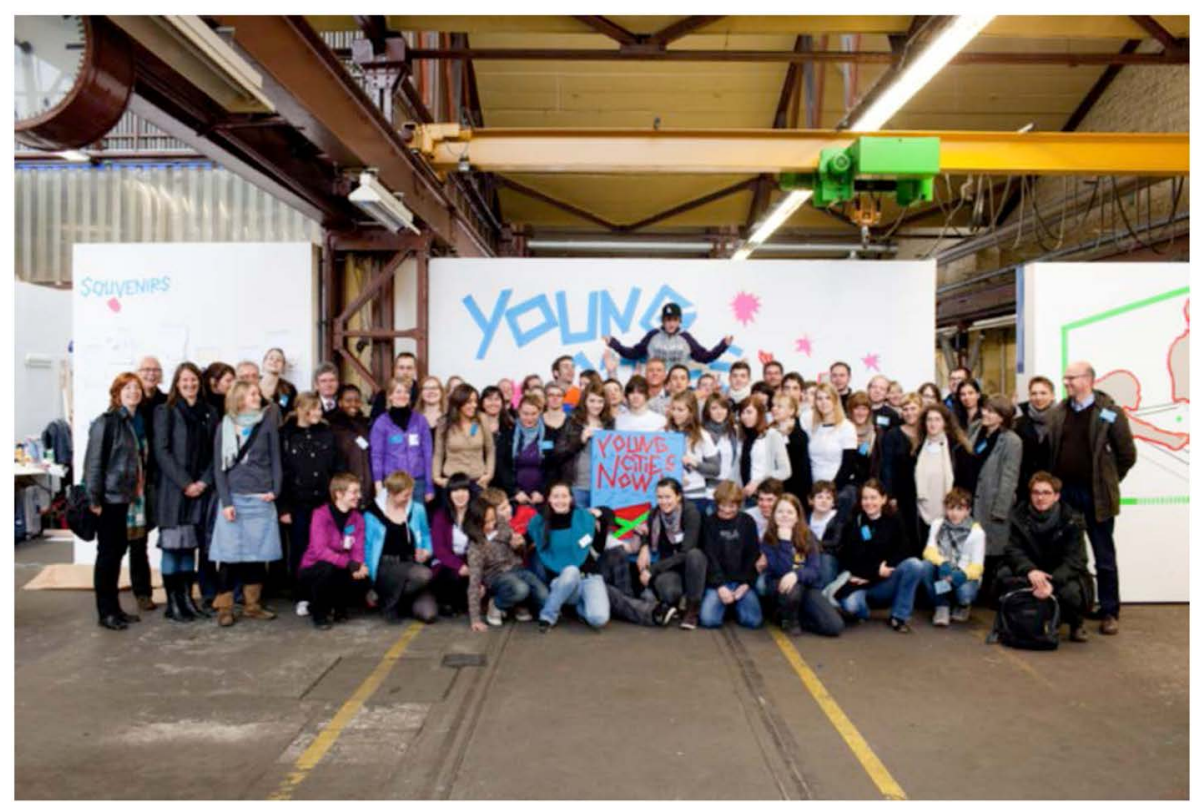

Figure 6. Final presentation of the "Young Cities Now!" manifesto to representatives from the Federal Ministry of Transport, Building and Urban Development (Photograph: A. Meichsner, Jugend Architektur Stadt e. V.)

In total the manifesto consists of eleven statements under the title "Live your city-bringing forward something new together. A manifesto for youth-friendly and liveable cities" (www.youngcitiesnow.de). The first statement is entitled "Future is Youth-Trust us!" and addresses youth participation explicitly. The adolescents criticise the lack of confidence in the abilities of young people that reduces their opportunities for action and participation. As one solution to this lack of confidence and the consequential lack of participation the adolescents consider empowerment and education. The young people suggest projects, seminars and workshops as possible formats of education. The value they see in a focused empowerment is

- a strengthening of interest in and motivation for youth participation and voluntary commitment amongst adolescents,

- a growth in the confidence of adults in adolescents,

- an improvement in the quality of life in cities, and

- an acquisition of soft skills and key competences for participation (JAS, 2009).

All written documents (posters, index cards, text blocks) from the one small group working on participation in general throughout the workshop were analysed via qualitative content analysis (Mayring, 2008). Additionally, an expert interview was conducted with the supervisor of the working group (Heinrich, 2010: pp. 21-22 and 24-25). The mass and diversity of points of discussion which could be identified from the working material shows the complexity and intensity of the adolescents' discussions about the issue of participation (Heinrich, 2010: pp. 32-35). Amongst other things the group discussed the right to participation, youths' willingness to get involved, cross-generational approaches to participation, adults' perception of young people (e.g. in view of respect, trust, prejudices), communication in participatory processes, places and opportunities for youth participation, voice opportunities and scope for design in planning processes, the potentials of young people for urban development and much more. Structuring the many issues raised and discussed by the adolescents, the analysis of the working material points out four major fields of actions in view of youth participation in urban processes:

5) conditions of youth participation,

6) formats for youth participation,

7) motivations for youth participation, and

8) topics and choice of topic for youth participation (Heinrich, 2010: pp. 27-28).

The analysis stresses that the young participants linked the subjects of education and in participation in all four dimensions of the analysis, even though education was not a topic brought up by the facilitators of the workshop. Within the first category of analysis—conditions of youth participation - the issue of education in 
planning processes was discussed by the young participants as a necessary prerequisite and condition of participation. Within processes of participation the adolescents expect support from adults, especially from politicians and the urban administration. They summarise their expectations with three key words: guidance, competence and learning. They describe that they want to be supported developing certain skills. On the one hand they want to adopt those skills through participation and on the other hand they feel they need to be trained for participation. They link this qualification closely to the matter of trust. "Trust us" is the most prominent claim of the youth's manifesto. The analysis suggests that the adolescents gain self-confidence from the empowerment and they hope to be able to enrich planning processes in a way which builds up a certain trust in youth in general (Heinrich, 2010: pp. 36-39; JAS, 2009).

In view of the second focus of analysis, namely the forms of participation, education was discussed with regard to two topics: Firstly, the adolescents call for the application of participatory methods, which guarantee an individual support of all youngsters. Secondly, they address youngsters and ask them to support each other within participation processes. They do not necessarily link the issue of education to adults and supervisors. They see a high potential in learning from one another (Heinrich, 2010: p. 39; JAS, 2009).

The third dimension of the analysis was the motivation for youth participation from different viewpoints. As an overall societal reason for participation the adolescents see a possible strengthening of society through participation because of the many educational effects participation incorporates. From their own perspective they also value participation because of its educational effects but again stress that participation necessarily needs educational elements as precondition for a high quality (Heinrich, 2010: pp. 40-41; JAS, 2009).

In view of topics and choice of topic for youth participation - the fourth analytical category-the youngsters state that generally they want to be allowed to participate in all contexts and discussions, not only those focused directly on youth. While they name concrete issues of participation such as economics, politics and sports, they also point out certain point out competencies they would like to strengthen such as media usage and to learn to do interviews (Heinrich, 2010: pp. 41-42; JAS, 2009).

In line with these findings the German Federal Institute for Research on Building, Urban Affairs and Spatial Development draws the following conclusion from the pilot projects of the research field "Adolescents in Urban Neighbourhoods": "Teenagers must be empowered in order to tap their potential. Therefore, foundations must be laid to enable them to formulate their interests. For this purpose, knowledge must be conveyed and technical languages translated or learned. Based on this, teenagers are given the possibility of becoming independent players in the quarters themselves” (BBSR, 2012).

\subsection{Lessons Learnt from the Practical Experience}

The EU-project "Fantasy Design in Community" started as built environment and design education project. "Young Cities Now!" however was conceptualised as a participation project. Both projects nevertheless emphasise a close connection between BEE and participation.

The evaluation of "Fantasy Design—Children in Community" shows that projects at the interface between built environment education and participation are recognised by the program authors themself as being different from pure educational projects. According to the level of motivation and willingness to acquire knowledge and skills the participants considered it purposeful to integrate learning processes in their projects. The young people enjoyed learning because it was meaningful. The participatory component in turn increased the authenticity of the project, as projects were involved in real community development processes. The opportunity to implement their own ideas in their local environment made the learning experience beneficial for the young people and at the same time expressed appreciation of the young people's commitment. Altogether, the evaluation clearly shows that one factor in the success of "Fantasy Design-Children in Community" was indeed the linkage between built environment education and participation.

The analysis of the workshop "Young Cities Now!" and the resulting manifesto reveals adolescents' viewpoint on participation and education. All participants were representatives of youth participation projects that focused on urban development. Based on their experience with community participation the adolescents clearly expressed that participation and built environment education are inseparable. Youth participation should be designed as an educational process, which allows the participants to learn from adults and from each other alike. For one thing the youths interpret BEE as a necessary prerequisite and condition of participation because of the high demands placed on participants. For another thing they see BEE as a means to support individuals through- 
out participation processes and thus to strengthen society as a whole.

As a lesson learnt from the analysis of the two projects "Fantasy Design in Community" and "Young Cities Now!" the authors understand built environment education as a supporting framework for participation (Figure 7). As such built environment advances participatory processes in view of the quality of results, the abilities of young people to analyse, reflect, criticise and to formulate own ideas keeping in mind demands and aims of other stakeholders and interest groups, and to present their results professionally. Moreover, young participants' motivation and the project's authenticity increase.

\section{Conclusions}

The theoretical discussion on linkages between built environment education and youth participation in community shows that meaningful education can benefit from participatory approaches and that participation automatically implies educational processes especially in view of civic education. The two practical examples introduced in this article-_Fantasy Design in Community" and "Young Cities Now!"- -added a further aspect to the current academic debate on participation and education. While youth participation and built environment education are mostly considered apart in theoretical and empirical studies so far, the practical experience emphasises that an integrated consideration is productive.

Based on the findings from the study cases the authors strongly recommend expanding the occasional educational processes within participation processes through a deliberate integration of built environment education. BEE should be an integral part of participation processes. Gained skills could foster process and product quality of youth participation. This would make participation a positive and formative experience and young people more knowledgeable participants.

The authors conclude that a debate on the inclusion of BEE in participation processes is necessary to enable young people to participate in urban planning processes. The discussion on linkages between the two fields of education and participation should hereby take into consideration the different degrees of participation. A question to be answered is whether there is a rising need for support and education in projects of a higher degree of participation. This enriches the on-going discussion on whether children and youths are able and capable to truly participate in community planning (Christensen \& O’Brien, 2003: p. 10).

The described first glimpses on the linkages between built environment education and youth participation in planning processes ask for proof and furthermore raise questions: What are in detail the interfaces between BEE and community participation? What exactly do young people learn participating in urban planning processes? Does experience from BEE indeed influence future commitment? How do BEE and participation complement

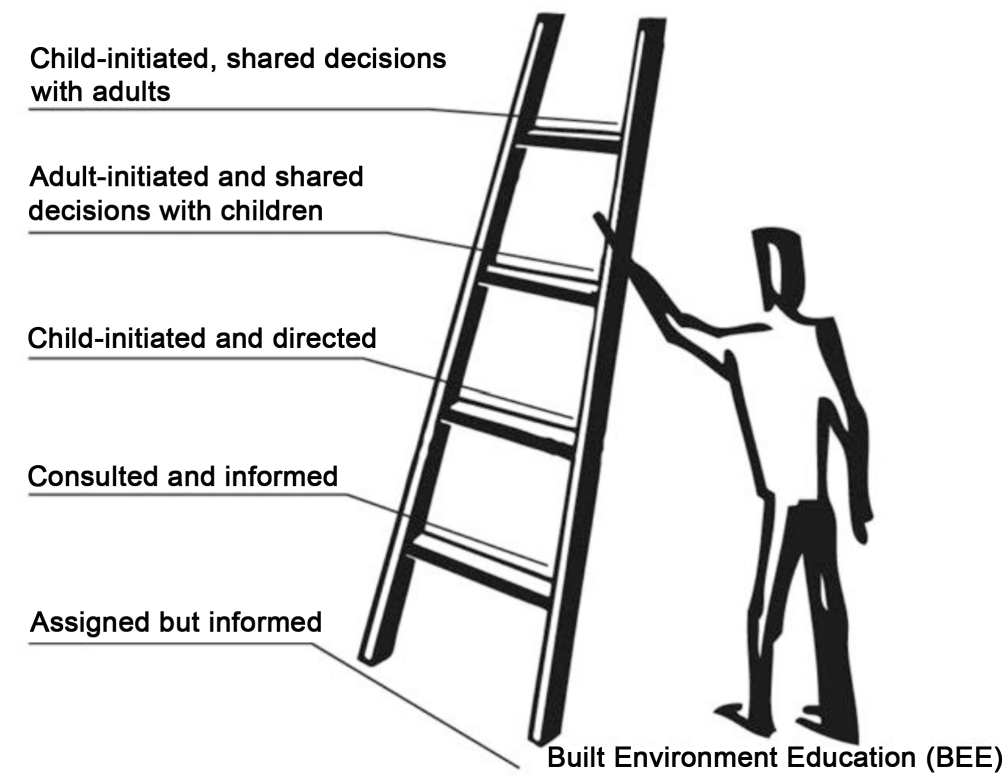

Figure 7. Participation and built environment education (own illustration). 
each other and where do the two approaches aim for contrary ethos, goals and aims that might conflict and how might these be resolved?

\section{References}

Adams, E. (2006) Shaping Places. Built Environment Design Education. Kent: Kent Architecture Centre.

Application Form to the EU Culture Programme: Education and Culture DG Application Fantasy Design in Community. Unpublished Manuscript.

BBSR. Bundesinstitut für Bau-, Stadt- und Raumforschung (Ed.) (2010a). Adolescents in Urban Neighbourhoods: Pilot Projects.

http://www.bbsr.bund.de/BBSR/DE/FP/ExWoSt/Forschungsfelder/2009/JugendlicheImStadtquartier/Jugendbeteiligung/04 Modellvorhaben_B.html?nn=430172

BBSR. Bundesinstitut für Bau-, Stadt- und Raumforschung (Ed.) (2010b). Adolescents in Urban Neighbourhoods: Young Cities now!

http://www.bbsr.bund.de/cln 016/nn 21888/BBSR/DE/FP/ExWoSt/Forschungsfelder/2010/JugendlicheImStadtquartier/ Modellvorhaben/YoungCitiesNow.html

BBSR. Bundesinstitut für Bau-, Stadt- und Raumforschung (Ed.) (2009a). Jugendliche im Stadtquartier. Katalog der Modellvorhaben [Adolescents in Urban Neighbourhoods. Catalogue of Pilot Projects]. Berlin: BBSR.

BBSR. Bundesinstitut für Bau-, Stadt- und Raumforschung (Ed.) (2009b). Innovationen für familien- und altengerechte Stadtquartiere. Ergebnisse des Forschungsfeldes [Innovations for Quarters Suited for Families and Elderly People. Results from the Research Field]. ExWoSt-Informationen, 32, 21-23.

BBSR. Bundesinstitut für Bau-, Stadt- und Raumforschung [Federal Institute for Research on Building, Urban Affairs and Spatial Development] (Ed.) (2012). Adolescents in Urban Neighbourhoods: Youth Participation. http://www.bbsr.bund.de/BBSR/EN/RP/ExWoSt/FieldsOfResearch/TeenagersUrbanQuarter/YouthParticipation/03_Result s.html;jsessionid=CF2F4442BEE3D3D4373FF5C107D47A02.live1043?nn=386162

Bertelsmann Stiftung (Ed.) (2007) Mehr Partizipation Wagen. Argumente für eine verstärkte Beteiligung von Kindern und Jugendlichen [Venture More Participation. Reasons for a Reinforced Participation of Children and Adolescents]. Gütersloh: Verlag Bertelsmann Stiftung.

Bertelsmann Stiftung (Ed.) (2009) Mitwirkung (er)leben. Handbuch zur Durchführung von Beteiligungsprojekten mit Kindern und Jugendlichen [Effect Action. A Handbook on the Implementation of Participation Projects for Children and Adolescents] (2nd ed.). Gütersloh: Verlag Bertelsmann Stiftung.

Betz, T., Gaiser, W., \& Pluto, L. (2011) Partizipation von Kindern und Jugendlichen. Diskussionsstränge, Argumentationslinien, Perspektiven [Participation of Children and Adolescents. Strands of Discussion, Lines of Argumentation, Perspectives]. In T. Betz, W. Gaiser, \& L. Pluto (Eds.), Partizipation von Kindern und Jugendlichen. Forschungsergebnisse und gesellschaftliche Herausforderungen (pp. 1-19). Schwalbach/Ts.: Wochenschau-Verlag.

Betz, T., Gaiser, W., \& Pluto, L. (Eds.) (2011). Partizipation von Kindern und Jugendlichen. Forschungsergebnisse und gesellschaftliche Herausforderungen (Participation of Children and Adolescents. Research Results and Societal Challenges). Schwalbach/Ts.: Wochenschau-Verlag.

BJK. Bundesjugendkuratorium (Federal Youth Panel) (Ed.) (2009). Partizipation von Kindern und Jugendlichen. Zwischen Anspruch und Wirklichkeit (Participation of Children and Adolescents. Contrast between Ideal and Reality). München: BJK.

BMVBS. Bundesministerium für Verkehr, Bau und Stadtentwicklung (Federal Ministry of Transport, Building and Urban Development) (Ed.) (2010). Jugendmacht Stadt. Junge Impulse für die Stadtentwicklung (Youth Builds Cities. Young Impulses for Urban Development). Berlin: BMVBS.

Christensen, P. M., \& O’Brien, M. (2003). Children in the City, Home, Neighborhood and Community. London and New York: Routledge.

Düx, W., \& Sass, E. (2005). Lernen in informellen Kontexten. Lernpotentiale in Settings des freiwilligen Engagements (Learning in Informal Settings. Learning Potential of Voluntary Engagement). Zeitschrift für Erziehungswissenschaft (Journal for Studies in Education), 8, 394-411. http://dx.doi.org/10.1007/s11618-005-0147-9

Engaging Places Network (Ed.) (2012a). What Is Built Environment Education All about? http://www.engagingplaces.org.uk/teaching\%20resources/art62811

Engaging Places Network (Ed.) (2012b). Built Environment Education. http://www.engagingplaces.org.uk/about\%20us/art63734

Francis, M., \& Lorenzo, R. (2002). Seven Realms of Children’s Participation. Journal of Environmental Psychology, 22, 157-169. http://dx.doi.org/10.1006/jevp.2001.0248 
Hafeneger, B. (2005). Beteiligung, Partizipation und bürgerschaftliches Engagement (Participation and Voluntary Engagement). In B. Hafeneger, M. M. Jansen, \& T. Niebling (Eds.), Kinder-und Jugendpartizipation. Im Spannungsfeld von Interessen und Akteuren (Participation of Children and Adolescents. Between Interests and Stakeholders) (pp. 11-40). Opladen: Barbara Budrich.

Hafeneger, B., Jansen, M. M., \& Niebling, T. (Eds.) (2005). Kinder-und Jugendpartizipation. Im Spannungsfeld von Interessen und Akteuren (Participation of Children and Adolescents. Between Interests and Stakeholders). Opladen: Barbara Budrich.

Hart, R. A. (1997). Children's Participation. The Theory and Practice of Involving Young Citizens in Community Development and Environmental Care. New York and London: UNICEF.

Hart, R. A. (2008). Stepping Back from “The Ladder”: Reflections on a Model of Participatory Work with Children. In A. Reid, B. B. Jensen, J. Nikel, \& V. Simovska (Eds.), Participation and Learning. Perspectives on Education and the Environment, Health and Sustainability (pp. 19-31). New York: Springer.

Heinrich, A. J. (2010). Young Cities Now! Qualifizierung der Jugendbeteiligung aus der Sicht von Jugendlichen. Eine qualitative Auswertung von Arbeitsunterlagen des Workshops "Young Cities Now!” zum Thema Jugendbeteiligung (Young Cities Now! Qualification of Youth Participation from Adolescent's Viewpoint. A Qualitative Analysis of Working Material from the Workshop "Young Cities Now!"). Unpublished Manuscript.

JAS. Jugend Architektur Stadt e. V. (Youth Architecture City) (Ed.) (2009). Young Cities Now! Jugend. Stadt. Labor. Ein Manifest von Jugendlichen für jugendgerechte und lebenswerte Städte (Young Cities Now! Youth. City. Laboratory. A Manifesto for Youth-Friendly and Livable Cities). http://youngcitiesnow.de/manifest/

Kapanen, H., \& Svinhufvud, L. (2011). Fantasy Design in Community. Helsinki: Design Museum Helsinki.

Knauer, R., \& Sturzenhecker, B. (2005). Partizipation im Jugendalter (Participation in Adolescents]. In B. Hafeneger, M. M. Jansen, \& T. Niebling (Eds.), Kinder- und Jugendpartizipation. Im Spannungsfeld von Interessen und Akteuren (Participation of Children and Adolescents. Between Interests and Stakeholders) (pp. 63-94). Opladen: Barbara Budrich.

Krings, E., \& Hasreiter, J. (1995). Gestaltung des Alltags. Kulturelle Bildung in Design and Baukultur. (Design of the Daily Life. Cultural Education in Design and Building Culture). Bonn: Deutscher Kulturrat.

Lerner, R. M., Alberts, A. E., \& Bobek, D. L. (2007). Engagierte Jugend-Lebendige Gesellschaft. Möglichkeiten zur Stärkung von Demokratie und sozialer Gerechtigkeit durch positive Jugendentwicklung (Engaged Youth—Lively Society. Opportunities to Strengthen Democracy and Social Justice through Positive Youth Development). Bielefeld: Bertelsmann Stiftung.

Lundy, L. (2007). “Voice” Is Not Enough: Conceptualising Article 12 of the United Nations Convention on the Rights of the Child. British Educational Research Journal, 33, 927-942. http://dx.doi.org/10.1080/01411920701657033

Mayring, P. (2008). Qualitative Inhaltsanalyse. Grundlagen und Techniken (10th ed.). Weinheim, Basel: Beltz Verlag.

Meinhold-Henschel, S. (2007a). Räume eröffnen im demokratischen Gemeinwesen (Open up Opportunities in a Democratic Community). In Bertelsmann Stiftung (Ed.), Kinder- und Jugendbeteiligung in Deutschland. Entwicklungsstand und Handlungsansätze (Participation of Children and Adolescents. State of Development and Actions Approaches) (pp. 9-17) Gütersloh: Verlag Bertelsmann Stiftung.

Meinhold-Henschel, S. (2007b). Qualitätsanforderungen an Beteiligungsvorhaben (Standards for Participation Projects]. In Bertelsmann Stiftung (Ed.), Kinder- und Jugendbeteiligung in Deutschland. Entwicklungsstand und Handlungsansätze (Participation of Children and Adolescents. State of Development and Actions Approaches) (pp. 221-245). Gütersloh: Verlag Bertelsmann Stiftung.

Moser, S. (2010). Beteiligt sein. Partizipation aus der Sicht von Jugendlichen (Participation from Adolescent's Viewpoint). Wiesbaden: VS Verlagfür Sozialwissenschaften.

Mullahey, R., Susskind, Y., \& Checkoway, B. (1999). Youth Participation in Community Planning. Chicago, IL: American Planning Association.

Niemann, L., Schauz, T., Andreas, V., Uttke, A., Heinrich, A. J., \& Edelhoff, S. (Authors); Bundesministerium für Verkehr, Bau und Stadtentwicklung (Ed.) (2013). Kompass Jugendliche und Stadtentwicklung (Compass Youth and Urban Development). Berlin: Bundesministerium für Verkehr, Bau und Stadtentwicklung [BMVBS].

Prein, G., Sass, E., \& Züchner, I. (2009). Lernen im freiwilligen Engagement und gesellschaftliche Partizipation (Learning through Voluntary Engagement and Societal Participation). Zeitschriftfür Erziehungswissenschaft (Journal for Studies in Education), 12, 529-547. http://dx.doi.org/10.1007/s11618-009-0086-y

Räsänen, J. (2006). Architecture Education in Finland. In E. Laaksonen, \& J. Räsänen (Eds.), Play + Space = Playce. Architecture Education for Children and Young People (pp. 13-17). Helsinki: Alvar Aalto Academy.

UIA, International Union of Architects (Ed.) (2008). Built Environment Education Guidelines (2nd ed.). http://www.riai.ie/public/downloads/uia_ed_guidelines.pdf 
Uttke, A. (2012). Towards the Future Design and Development of Cities with Built Environment Education. Experiences of Scale, Methods, and Outcomes. Procedia-Social and Behavioral Sciences, 45, 3-13. http://dx.doi.org/10.1016/j.sbspro.2012.06.537

Uttke, A., \& Heinrich, A. J. (2012) Evaluation of the International Project Fantasy Design in Community. Unpublished Manuscript.

Winklhofer, U., \& Zinser, C. (2008). Jugend und gesellschaftliche Partizipation (Youth and Societal Participation). In G. Bingel, A. Nordmann, \& R. Münchmeier (Eds.), Die Gesellschaft und ihre Jugend. Strukturbedingungen jugendlicher Lebenslagen (The Society and Its Youth. Structural Conditions of Adolescent's Situation) (pp. 71-93). Opladen and Farmington Hills, MI: Barbara Budrich. 
Scientific Research Publishing (SCIRP) is one of the largest Open Access journal publishers. It is currently publishing more than 200 open access, online, peer-reviewed journals covering a wide range of academic disciplines. SCIRP serves the worldwide academic communities and contributes to the progress and application of science with its publication.

Other selected journals from SCIRP are listed as below. Submit your manuscript to us via either submit@scirp.org or Online Submission Portal.
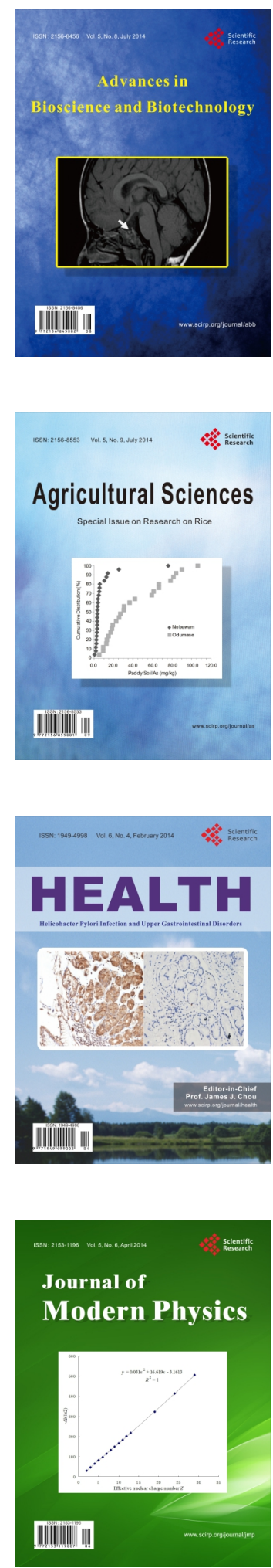
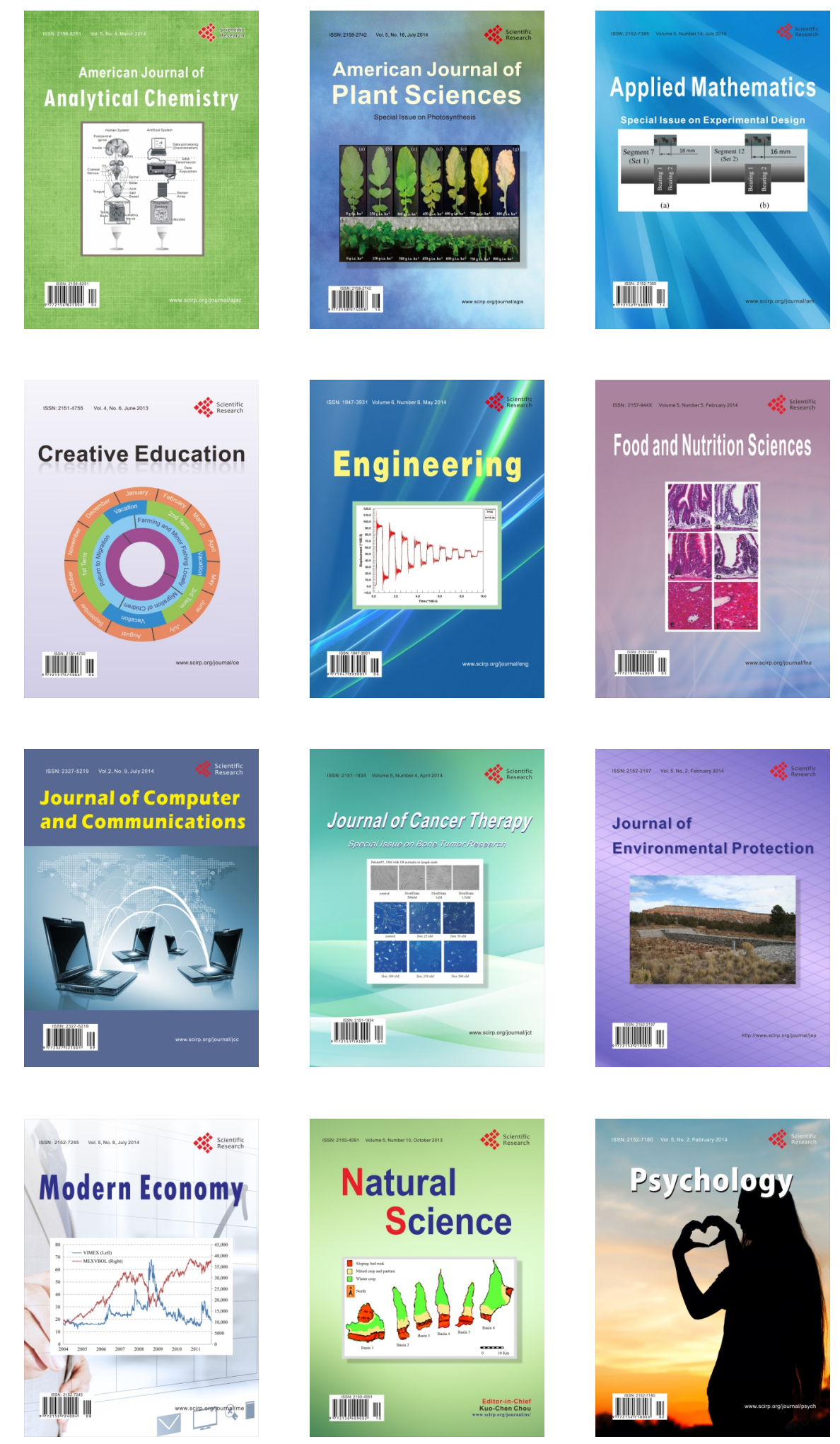